\title{
Health Beliefs of the Female Academicians About Breast Cancer and Screening Tests and the Affecting Factors
}

\author{
Nuriye B. DUMAN ${ }^{1}$, Lale ALGIER ${ }^{2}$, Gul PINAR ${ }^{3}$ \\ ${ }^{1}$ Hitit University The School of Health, Corum \\ ${ }^{2}$ Koc University The School of Nursing, Istanbul \\ ${ }^{3}$ Yıldırım Beyazıt University, Faculty of Health Sciences, Ankara, TURKEY
}

\begin{abstract}
This was a descriptive research conducted in order to determine health beliefs of the female academicians about breast cancer and screening tests and the Affecting factors that determined these beliefs. 200 female academicians made up the sample of the research. The data were gathered by the researcher using a Descriptive Data Collection Form that aimed at the characteristics of the women and Champion's Health Belief Model Scale (HBMS) for breast cancer and were evaluated using percentages, arithmetical means, standard deviations and Mann Whitney $U$ test in computer environment. It was found out in the study that the female academicians who had family cancer history, acquired knowledge about breast cancer and whose academic specialty was on health presented higher mean scores in "susceptibility" and "seriousness" and "breast-self-examination self-efficacy" of HBMS but their mean scores of "barriers to breast-self-examination" and "barriers to mammography" were lower as compared with other women. This difference was statistically significant $(p<0.05)$. As a result; it was established that female academicians were susceptible to breast cancer, cared about it, had higher health motivation, believed in the benefits of breast self examination (BSE) and mammography and in the efficacy of the BSE. However, female academicians' perceptions about "barriers to BSE" and "barriers to mammography" were high.
\end{abstract}

Keywords: Breast cancer, Screening tests, Health beliefs, Affecting factors, Female academicians

\section{ÖZET}

\section{Bayan Akademisyenlerin Meme Kanseri ve Tarama Testlerine İlişkin Sağlık İnançları ve Etkileyen Faktörler}

Bu çalışma, akademisyen kadınların meme kanseri ve tarama testlerine ilişkin sağlık inançlarını ve bunları etkileyen faktörleri belirlemek amacıyla yapıımış tanımlayıcı nitelikte bir çalışmadır. Araştımanın örneklemini 200 akademisyen kadın oluşturmuştur. Veriler, araştırmacı tarafından literatür bilgileri kullanılarak hazırlanan kadınlara ilişkin özellikleri tanımlayıcı veri toplama formu ile Champion'un meme kanseri ve taramalarına ilişkin Sağılı İnanç Modeli Ölçeği (SiMÖ) kullanılarak toplanmış ve bilgisayar ortamında yüzdelik oranlar, aritmetik ortalama, standart sapma ve Mann Whitney U testi ile değerlendirilmiştir. Çalışmada, ailesinde kanser öyküsü olan, meme kanserine yönelik bilgisi olan ve çalışma alanı sağlıkla ilgili olan kadınların duyarlılık algısı, önemseme algısı ve kendi kendine meme muayenesi (KKMM) öz etkililiği SiMÖ alt boyutlarından aldıkları puan ortalamalarıın diğer kadınlara göre daha yüksek olduğu, KKMM ve mamografi engelleri SiMÖ alt boyutlarından aldıkları puan ortalamalarının ise daha düşük olduğu belirlenmiştir. Bu fark istatistiksel olarak önemli bulunmuştur $(p<0.05)$. Sonuç olarak çalışmada akademisyen kadınların meme kanserine karşı duyar॥ oldukları, kanseri önemsedikleri ve sağllk motivasyonlarının yüksek olduğu, KKMM ve mamografinin yararına inandıkları ve KKMM'nin etkinliğine inandıkları tespit edilmiştir. Ancak, kadınların KKMM ve mamografi uygulamalarına yönelik engel algıları yüksek bulunmuştur.

Anahtar Kelimeler: Meme kanseri, Tarama testleri, Sağlık inançları, Etkileyen faktörler, Akademisyen kadınlar 


\section{INTRODUCTION}

Today, breast cancer is the most widely diagnosed cancer type among women across the world and is a cancer related mortality cause. According to World Health Organization (WHO); following cervix cancer, breast cancer occupies the second place in terms of incidence and mortality rate in Africa. In the United States and Europe, the most commonly seen cancer type is breast cancer among women in terms of case number. ${ }^{1}$ In Turkey, also, breast cancer comes first among the top ten cancer types seen among women. According to the Annual Book of Health Statistics of Ministry of Health of Turkish Republic, incidence of breast cancer which was $37.6 \%$ in 2006 rose to $41.6 \%$ in 2008 in our country. In fact, breast cancer is a curable and treatable disease the diagnosis of which is possible at an early period thanks to breast self examination (BSE) and screening methods like mammography. The most important mortality cause of breast cancer is its too-late diagnosis at end-stage in which the treatment is not possible. However, screening methods that provide an early diagnosis of breast cancer are not used enough by women ${ }^{3-6}$; the most significant reason is -may be- women's negative health beliefs and attitudes towards breast cancer and screening methods. The studies conducted point out that breast cancer awareness and health behaviors of women were poor and not sufficient..$^{3-11}$ Therefore; it is vital to enhance women's breast cancer awareness, to develop positive health beliefs and attitudes among them and to increase the number of screening methods in order to diagnose breast cancer at primary care and to decrease mortality rate. There are various studies that have investigated health beliefs of women about breast cancer on different groups in our country. ${ }^{9-17}$ However, we were of the opinion that it was highly important to determine female academicians' health beliefs about breast cancer and screening tests so that general perspectives and awareness of women with high educational status about breast cancer could be understood; which was the main determinant to plan our study. Our study was conducted in order to determine health beliefs of the female academicians about breast cancer and screening tests and the factors that determined these beliefs.

\section{MATERIALS AND METHODS}

\section{Type of the Research}

The current research was a descriptive research conducted in order to determine health beliefs of the female academicians about breast cancer and screening tests, and the factors that determined these beliefs.

\section{Population and Sample of the Research}

The population of the research was composed of 230 female academicians who taught at schools and faculties of Hitit University during 2010-2011 academic year. The sample of the research was consisted of 200 female academicians who volunteered to participate between January 2011 and February 2011.

\section{Data Collection Tools}

The data were gathered by the researcher using a Descriptive Data Collection Form that aimed at the characteristics of the female academicians and was designed through the literature information and Champion's Health Belief Model Scale (HBMS) for Breast Cancer and Breast Cancer Screening.

\section{Descriptive Data Collection Form of the charac- teristics of Female Academicians}

Descriptive Data Collection Form that aimed at the characteristics of the female academicians contained a total of 13 questions that targeted at sociodemographic information (age, educational status, marital status, status of having a child, academic title, academic specialty, etc.) and knowledge, behaviors and attitudes of female academicians about breast cancer and screening tests (family history of breast cancer, having knowledge about cancer and screening tests, person/institutions through whom/which they received training about breast cancer and screening tests, status of breast-self-examination (BSE), reasons not to perform BSE, status of having mammography, etc.).

\section{Champion's Health Belief Model Scale (HBMS)} for Breast Cancer and Breast Cancer Screening

HBMS was introduced by Champion and was based on health belief model scale for early diagnosis of breast cancer. ${ }^{18}$ Turkish version, validity and reliability tests were performed by Karayurt and Dramal $1^{10}$ and Gozum and Aydın ${ }^{19}$. Cronbach's alpha reliability coefficients for the HBMS subscales ran- 
ged from $0.69-0.83$ in the Turkish version made by Gozum and Aydın whereas these coefficients varied from 0.58 to 0.89 in the Turkish version made by Karayurt. Test-retest reliability was between 0.89 and $0.99 .^{10,19}$ Validity and reliability of HBMS were found to be satisfactory in both studies. In our study, the Turkish version of Gozum and Aydın (2004) was used.

The Turkish version of the HBMS which measured one's judgments about breast cancer and general health was consisted of 57 items that were clustered into eight subscales: susceptibility (three items), seriousness (six items), health motivation (five items), barriers to BSE (eight items), benefits of BSE (four items), BSE self-efficacy (ten items), benefits of mammography (five items) and barriers to mammography (eleven items). The scale items have a 5 -point Likert format with the following coding: I strongly disagree (1 point), I disagree ( 2 points), I am neutral (3 points), I agree (4 points), and I strongly agree (5 points). Higher scores indicate higher "susceptibility" and "seriousness". Higher scores of "health motivation" indicate that health motivation is highly perceived, higher scores of "benefit" indicate that benefit is highly perceived, higher scores of "barrier" indicate that barrier is highly perceived and higher score of "self-efficacy" indicate that self-efficacy is highly perceived.

\section{Data Evaluation}

Data were evaluated using SPSS 17.0 statistical package software in computer environment. Percentages, arithmetical means, standard deviations were used in the analyses of the data. For the pairwise comparisons of the parameters that did not follow a normal distribution, Man Whitney-U test was used.

\section{Ethical Considerations}

The Principles set out by the Declaration of Helsinki and national and local ethical guidelines for research were also followed. The necessary official permissions were obtained from the university to undertake pre-administration and administration phase of the study at the faculties and schools of Hitit University. The participants were thoroughly instructed in the aims and details of the study, an information sheet was provided and informed consent was obtained. Participants signed the consent form

\begin{tabular}{|c|c|c|}
\hline Characteristics & $\mathbf{n}$ & $\%$ \\
\hline \multicolumn{3}{|l|}{ Age* $^{*}$} \\
\hline $23-28$ & 95 & 47.5 \\
\hline $29-34$ & 70 & 37.5 \\
\hline $35-43$ & 35 & 17.5 \\
\hline \multicolumn{3}{|l|}{ Educational Status } \\
\hline Undergraduate & 94 & 47.0 \\
\hline Master & 70 & 35.0 \\
\hline Doctorate & 36 & 18.0 \\
\hline \multicolumn{3}{|l|}{ Academic Title } \\
\hline Research Assistant /Specialist & 90 & 45.0 \\
\hline Instructor & 75 & 37.5 \\
\hline Assistant Professor & 35 & 17.5 \\
\hline \multicolumn{3}{|l|}{ Academic Branch } \\
\hline Social Sciences & 100 & 50.0 \\
\hline Physical Sciences & 95 & 47.5 \\
\hline Health Sciences & 5 & 2.5 \\
\hline \multicolumn{3}{|l|}{ Marital Status } \\
\hline Married & 95 & 47.5 \\
\hline Unmarried & 105 & 52.5 \\
\hline \multicolumn{3}{|l|}{ Status of having children } \\
\hline Yes & 93 & 46.5 \\
\hline No & 107 & 53.5 \\
\hline Total & 200 & 100.0 \\
\hline
\end{tabular}

knowing that they could withdraw from the study at any time. The anonymity and confidentiality of participants were guaranteed and those who volunteered to participate were recruited for the study.

\section{RESULTS}

Mean age of the participant female academicians was $36 \pm 1.2$ (min: 23 - max: 43). Nearly one of the two women was married $(47.5 \%)$ and had child/children (46.5\%). Also, nearly one of the two women $(47.0 \%)$ had under-graduate degree, nearly one of the three women $(35.0 \%)$ had graduate degree and one of the five women had doctorate degree 


\begin{tabular}{|c|c|c|}
\hline Characteristics & $\mathbf{n}$ & $\%$ \\
\hline \multicolumn{3}{|l|}{ Family breast cancer history* $\mathrm{n}: 200$} \\
\hline Yes & 10 & 5.0 \\
\hline No & 190 & 95.0 \\
\hline \multicolumn{3}{|c|}{ Knowledge about breast cancer and screening tests $n: 200$} \\
\hline Yes & 160 & 80.0 \\
\hline No & 40 & 20.0 \\
\hline \multicolumn{3}{|c|}{$\begin{array}{l}\text { Person/institutions through whom/which they received train- } \\
\text { ing about breast cancer and screening tests } n: 160^{\star *}\end{array}$} \\
\hline Family Members & 10 & 6.3 \\
\hline Friends & 45 & 28.1 \\
\hline Health Care Personnel & 100 & 62.5 \\
\hline Mass media & 150 & 93.8 \\
\hline \multicolumn{3}{|l|}{ Status of performing BSE n: 200} \\
\hline Yes & 20 & 10.0 \\
\hline No & 180 & 90.0 \\
\hline \multicolumn{3}{|l|}{ Reasons for not performing BSE $n$ : $180^{\star \star}$} \\
\hline Laziness and negligence & 80 & 44.4 \\
\hline Fear to find lumps & 72 & 40.0 \\
\hline Having no knowledge about BSE & 40 & 22.2 \\
\hline \multicolumn{3}{|l|}{ The idea that it is unnecessary } \\
\hline to perform BSE routinely & 27 & 15.0 \\
\hline \multicolumn{3}{|l|}{ Status of having mammography $\mathrm{n}: 200$} \\
\hline Yes & 2 & 1.1 \\
\hline No & 198 & 98.9 \\
\hline \multicolumn{3}{|c|}{ Reasons for not having mammography $\mathrm{n}$ : $198^{* *}$} \\
\hline Being too young to have mammography & 180 & 90.9 \\
\hline Its painful procedure & 170 & 85.8 \\
\hline Embarrassment & 150 & 75.7 \\
\hline Laziness and negligence & 180 & 85.8 \\
\hline Fear to find lumps & 180 & 85.8 \\
\hline $\begin{array}{l}\text { The idea that it is unnecessary } \\
\text { to have mammography routinely }\end{array}$ & 90 & 45.4 \\
\hline \multicolumn{3}{|c|}{$\begin{array}{l}{ }^{*} \text { First degree relatives (grandmother, mother, maternal aunt, paternal } \\
\text { aunt, sister) } \\
{ }^{* *} \text { Percentages were calculated by n because more than one answer } \\
\text { was given. }\end{array}$} \\
\hline
\end{tabular}

$(17.5 \%)$. When the academic titles of the participants were analyzed, it was seen that eight of the ten women were appointed as instructors and research assistants $(82.5 \%)$ and nearly one fifth were assistant professors (17.5\%). One of the two women $(47.5 \%)$ specialized in physical sciences and social sciences but only $2.5 \%$ of the female academicians specialized in health sciences (Table 1).

First degree relatives (mother/maternal aunt/paternal aunt/sister/grandmother) of only $5 \%$ of the participants had breast cancer history. It was explored in the study that eight of the ten female academicians had knowledge about breast cancer and screening tests. The person/institution through whom/which they acquired training about breast cancer and screening tests were mass media (93.8\%), health personnel (62.5\%), friend (28.1\%) and family members (6.3\%); relatively. None of the participants performed BSE regularly and only one of the ten women occasionally performed BSE. The reasons for which the participants did not perform BSE were "laziness and negligence" (44.4\%), "fear to find lumps" (40.0\%), "having no knowledge about BSE" (22.2\%) and "the idea that it is unnecessary to perform BSE routinely" (15.0\%); respectively. It was detected that only two academicians had mammography. The reasons for which the participants did not have mammography were "being too young to have mammography" (90.9\%), "its painful procedure" (85.8\%), "fear to find lumps" $(85.5 \%)$, "embarrassment" (75.7\%) and "the idea that it is unnecessary to have mammography routinely" (45.4\%) (Table 2).

When the distributions related to mean scores of HBMS subscales of the participant female academicians were analyzed; it was found out that their "susceptibility" was $11.79 \pm 1.40$, "seriousness" was $25.06 \pm 5.09$, "health motivation" was $19.91 \pm$ 3.49, "benefits of BSE" was $19.66 \pm 1.04$, "barriers to BSE" was $20.83 \pm 4.13$, "BSE self-efficacy" was 19. $95 \pm 5.33$, "benefits of mammography" was $17.55 \pm 5.33$ and "barriers to mammography" was $41.55 \pm 9.36$. According to these findings, mean scores of the female academicians were higher in the subscales of "susceptibility", "seriousness", "health motivation", "benefits of BSE", "barriers to BSE", "BSE self-efficacy", "benefits of mammography" and "barriers to mammography" (Table 3). 


\begin{tabular}{|llll|}
\hline $\begin{array}{l}\text { Table 3. Distributions of female academicians about mean } \\
\text { scores of HBMS subscales in terms of breast cancer and } \\
\text { screening tests }\end{array}$ & 土 SD & Min. & Max. \\
\hline HBMS subscales & $11.79 \pm 1.40$ & 7 & 13 \\
\hline Susceptibility & $25.06 \pm 5.09$ & 10 & 30 \\
Seriousness & $19.91 \pm 3.49$ & 10 & 24 \\
Health motivation & $19.66 \pm 1.04$ & 15 & 20 \\
Benefits of BSE & $20.83 \pm 4.13$ & 10 & 30 \\
Barriers to BSE & $19.95 \pm 5.33$ & 10 & 40 \\
BSE self-efficacy & $17.55 \pm 5.33$ & 5 & 25 \\
Benefits of mammography & $41.55 \pm 9.36$ & 20 & 55 \\
Barriers to Mammography & 40 \\
\hline
\end{tabular}

It was found out in the study that the female academicians who had knowledge about breast cancer had higher mean scores in "susceptibility" and "seriousness", "health motivation", "BSE self-efficacy" and "benefits of mammography" compared to those who did not have any knowledge about breast cancer but their mean scores of "barriers to BSE" and "barriers to mammography" were lower. This statistical difference was considered significant $(\mathrm{p}<0.05)$. Our study demonstrated that the difference between mean scores of "benefits of BSE" was statistically not significant among the female academicians with and without knowledge about breast cancer ( $>0.05)$ (Table 4.).

It was established in the study that female academicians who had family breast cancer history had higher mean scores in "susceptibility and seriousness", "benefits of BSE" and "BSE self-efficacy" compared to those who did not have family breast cancer history but their means scores in "barriers to BSE" and "barriers to mammography" were lower. This statistical difference was considered significant $(\mathrm{p}<$ $0.05)$. Our study indicated that the difference between mean scores of "health motivation" and "benefits of mammography" was statistically not significant among the female academicians with and without family breast cancer history ( $p>0.05$ ) (Table 4).

It was found out that those whose academic specialty was on health had higher mean scores in susceptibility and seriousness, health motivation, BSE self-efficacy and benefits of mammography compared to those whose academic specialty was not on health but their mean scores in "barriers to BSE" and "barriers to mammography" was lower. This statistical difference was considered significant $(\mathrm{p}<$ $0.05)$. On the other hand, no statistical difference existed between mean scores in "benefits of BSE" among those whose academic specialty was on health or on a different academic field ( $p>0.05)$ (Table 4). Although not shown in the table, the difference between mean scores of female academicians was statistically not significant in terms of age, educational status, academic title, marital status and having child/children $(\mathrm{p}>0.05)$.

\section{DISCUSSION}

According to WHO breast cancer is the first most common cancer-related death cause among the women across the world. 411.000 women die due to breast cancer each year; which makes up $1.6 \%$ of all cause mortality of women. Death to case ratio is highest in countries with low and middle income levels. ${ }^{1}$ It is estimated that breast cancer incidence has recently gone up and there will be more than 51.000 breast cancer case..$^{23}$ Inability to detect the disease at an early period is the leading death cause of breast cancer. $38 \%$ of the breast cancer cases in Europe and 30\% of the breast cancer cases in the USA are locally progressed cancers at the time of diagnosis. ${ }^{1}$ Therefore, breast cancer should be detected with an early diagnosis and treatment should be initiated as early as possible using BSE and mammography which are perhaps the most effective methods. Yet, it is reported in the studies on the issue that women's breast cancer screening rate is low. ${ }^{3-8}$ Besides, women's health beliefs on screening methods generally affect utilization-rate of BSE, mammography and other methods.

In our study, mean scores of the female academicians were higher in the subscales of HBMS of susceptibility (11.79 \pm 1.40$)$, seriousness $(25.06 \pm 5.09)$, health motivation $(19.91 \pm 3.49)$, benefits of BSE (19.66 \pm 1.04$)$, barriers to BSE $(20.83 \pm 4.13)$, BSE self-efficacy $(19.95 \pm 5.33)$, benefits of mammography $(17.55 \pm 5.33)$ and barriers to mammography $(41.55 \pm 9.36)$. When compared with other relevant studies conducted in our country ${ }^{10-17}$; it was noted that mean scores of our study were higher in "sus- 


\begin{tabular}{|c|c|c|c|c|c|c|}
\hline \multirow[t]{2}{*}{ HBMS Subscales } & \multicolumn{2}{|c|}{ Family breast cancer history } & \multicolumn{2}{|c|}{$\begin{array}{l}\text { Status of having knowledge } \\
\text { about breast cancer }\end{array}$} & \multicolumn{2}{|c|}{$\begin{array}{l}\text { Status of teaching } \\
\text { in health sciences }\end{array}$} \\
\hline & $\begin{array}{l}\text { Yes } \\
\pm \text { SD }\end{array}$ & $\begin{array}{l}\text { No } \\
\pm \text { SD }\end{array}$ & $\begin{array}{l}\text { Yes } \\
\pm \text { SD }\end{array}$ & $\begin{array}{l}\text { No } \\
\pm \text { SD }\end{array}$ & $\begin{array}{l}\text { Yes } \\
\pm \text { SD }\end{array}$ & $\begin{array}{l}\text { No } \\
\pm \text { SD }\end{array}$ \\
\hline \multirow[t]{2}{*}{ Susceptibility } & $13.00 \pm 0.00$ & $11.73 \pm 1.41$ & $12.13 \pm 1.09$ & $10.50 \pm 1.71$ & $13.00 \pm 0.00$ & $11.76 \pm 1.41$ \\
\hline & U: 420.000 & p: $0.002^{*}$ & U: 1.436 .000 & p: $0.000^{*}$ & U: 222.500 & p: $0.027^{\star}$ \\
\hline \multirow[t]{2}{*}{ Seriousness } & $28.50 \pm 1.58$ & $24.85 \pm 5.15$ & $26.16 \pm 3.98$ & $20.85 \pm 6.64$ & $30.00 \pm 0.00$ & $24.91 \pm 5.10$ \\
\hline & U: 470.000 & p: $0.005^{*}$ & U: 1.588 .000 & p: $0.000^{\star}$ & U: 102.500 & p: $0.002^{*}$ \\
\hline \multirow[t]{2}{*}{ Health Motivation } & $21.00 \pm 3.16$ & $19.84 \pm 3.52$ & $20.82 \pm 2.43$ & $16.35 \pm 4.59$ & $24.00 \pm 0.00$ & $19.79 \pm 3.49$ \\
\hline & U: 865.000 & p: 0.625 & U:1.359.000 & p: $0.000^{\star}$ & U: 85.000 & p: $0.001^{*}$ \\
\hline \multirow[t]{2}{*}{ Benefits of BSE } & $19.10 \pm 0.32$ & $19.68 \pm 1.06$ & $19.85 \pm 0.36$ & $19.60 \pm 1.14$ & $20.00 \pm 0.00$ & $19.65 \pm 1.05$ \\
\hline & U: 268.500 & p: $0.000^{\star}$ & U: 3.101 .000 & p: 0.640 & U: 407.500 & p: 0.326 \\
\hline \multirow[t]{2}{*}{ Barriers to BSE } & $28.50 \pm 2.42$ & $20.26 \pm 3.87$ & $21.78 \pm 3.47$ & $16.88 \pm 4.19$ & $15.00 \pm 0.00$ & $20.97 \pm 4.07$ \\
\hline & U: 105.500 & p: $0.000^{\star}$ & U: 1.476 .000 & p: $0.000^{\star}$ & U: 50.000 & p: $0.000^{\star}$ \\
\hline \multirow[t]{2}{*}{ BSE Self-Efficacy } & $22.50 \pm 2.64$ & $19.82 \pm 5.40$ & $19.97 \pm 2.89$ & $19.75 \pm 10.5$ & $25.00 \pm 0.00$ & $19.82 \pm 5.33$ \\
\hline & U: 532.500 & p: $0.002^{*}$ & U: 2.555 .500 & p: $0.008^{\star}$ & $\mathrm{U}: 67.500$ & p: $0.000^{*}$ \\
\hline \multirow[t]{2}{*}{ Benefits of mammography } & $13.50 \pm 9.14$ & $17.76 \pm 5.00$ & $18.72 \pm 4.17$ & $12.88 \pm 6.78$ & $22.00 \pm 2.74$ & $17.44 \pm 5.33$ \\
\hline & U: 744.500 & p: 0.129 & U: 1.726 .500 & p: $0.000^{\star}$ & U: 240.500 & p: $0.011^{\star}$ \\
\hline \multirow[t]{2}{*}{ Barriers to mammography } & $52.00 \pm 4.22$ & $41.00 \pm 9.23$ & $44.59 \pm 5.88$ & $29.00 \pm 10.08$ & $49.00 \pm 4.18$ & $41.36 \pm 9.38$ \\
\hline & U: 238.000 & p: $0.000^{*}$ & U: 783.000 & p: $0.000^{*}$ & U: 198.000 & p: $0.014^{*}$ \\
\hline
\end{tabular}

ceptibility", "seriousness", "health motivation", "benefits of BSE", "BSE self-efficacy" and "benefits of mammography" than the above mentioned studies. Based on these findings; it could be suggested that the participant female academicians were susceptible to and cared about breast cancer much, their awareness of breast cancer were at a high level and believed in the benefit of BSE and mammography. However; means scores of female academicians in "barriers to BSE" and "barriers to mammography" were high; which made us conclude that female academicians had higher perceptions/negative perceptions about barriers to scre- ening methods. Therefore; it may be argued that the participant women avoided performing BSE and having mammography although they cared about breast cancer and believed in benefits and efficacy of screening methods.

BSE is a very effective method for an early diagnosis and prevention of breast cancer. According to WHO, $90 \%$ of the women in whom breast cancer is diagnosed go to the clinics after they have detected mass/masses in their breasts using BSE. ${ }^{1}$ Therefore, it is very significant that women should know their own breasts and should develop awareness towards 
the changes in their breasts. But according to our study findings, none of the participants performed BSE regularly and only $10 \%$ of the women occasionally performed BSE. Main reason for which the participants did not perform BSE was "laziness and negligence". It was also found out in the study that one of the five female academicians did not have knowledge about BSE and one of six female academicians regarded that it was unnecessary to perform BSE routinely.

As for mammography, only two women had mammography. When we considered the mean age of the participant women, low mammography rate may have resulted from the fact that their ages were not suitable/too young for mammography. Yet, most of the women regarded mammography as a painful procedure and experienced embarrassment and fear for mammography. Moreover, nearly one of the two women did not find routine mammography checks necessary.

Breast cancer screening with mammography is a very effective way to reduce mortality caused by breast cancer. In fact, it is expected to achieve $20 \%$ decrease in mortality thanks to mammography among the women aged $\geq 50$ years. It is still a debated issue whether or not mammography is necessary for women aged $<50$ years. However, more than $40 \%$ of the deaths caused by breast cancer diagnosed among those aged $<80$ occur among the women aged between 35 and 49 . Therefore, it is highly important to create awareness in terms of the early diagnosis of breast cancer among women aged $<50$ years. ${ }^{1}$

Another considerable finding of the study was that female academicians avoided from BSE (40.0\%) and mammography ( $85.8 \%$ ) because they feared to find lumps; which pointed out that education is not enough to develop positive health behaviors about early diagnosis methods of breast cancer although our participants may have higher educational status. In accordance with the result of our study, the studies of Lostao and et al. and Dewal reported that majority of the women did not perform regular BSE and that those who occasionally performed BSE did it wrong. ${ }^{20-21}$ Similarly, "barriers to mammography" of the women were high in these studies. ${ }^{20-21}$ When the literature is analyzed, it is seen that rate of women who perform BSE is much bigger in European and American countries than African and Asian countries. $^{3-8}$

In the studies on relevant issue made in Turkey with women with different characteristics, it was emphasized that rate of BSE was low. ${ }^{9-17}$ In agreement with our finding, the study of Altunkan et al., reported that none of the women aged 20-60 performed BSE regularly and only $13.8 \%$ of the women performed BSE occasionally. ${ }^{16}$ The study of Merey demonstrated that nearly all of the women did not perform BSE regularly. ${ }^{9}$ The studies made on this issue showed that main reasons for women's negative thoughts and attitudes about breast cancer early diagnosis methods were the fear to find lump and the opinion that breast cancer was an incurable disease although it was early diagnosed. ${ }^{3-8,17}$ These findings concurred with our findings.

Our study did not reveal any correlation between mean scores of HBMS subscales and age, educational status, academic title, marital status and having a child/children. When the literature was analyzed, it was understood that there were different study results. The study of Dündar et al., which was in agreement with our results, indicated that age, marital status and educational level did not affect the status of performing BSE. ${ }^{12}$ As for the studies of Nahçıvan and Seçginli, it reported no correlation between marital status and BSE. ${ }^{14}$ Likewise, the study of Altunkan et al. suggested that age, educational status and having a child/children did not affect women's susceptibility towards breast cancer. ${ }^{16}$ On the other hand, unlike our study, the same study reported that women who were aged below 39 , had primary school degree or below and did not have children had higher "barriers to BSE". Besides, the same study demonstrated that "benefit of BSE" of women increased as age decreased and educational level increased. ${ }^{16}$ But the studies of Petro- Nustus and Mikhail presented a positive correlation between rate of BSE and advanced age and increased educational level, too. ${ }^{4}$ Similarly, the studies of Jarvandi et al. argued that those who were married and older performed BSE more often. ${ }^{5}$

It was found out in the study that the female academicians who had family cancer history, acquired knowledge about breast cancer and whose academic specialty was on health presented higher mean scores in "susceptibility" and "seriousness" and 
"BSE self-efficacy" of HBMS but their mean scores of "barriers to BSE" and "barriers to mammography" were lower as compared with other women. This difference was statistically significant. According to the findings of the study, the female academicians who had family cancer history, acquired knowledge about breast cancer and those whose academic specialty was on health were more susceptible towards and cared about breast cancer more and had positive behaviors about how to perform BSE and about its efficacy. Besides, these women considered BSE and mammography easier or unproblematic. Health beliefs and knowledge about breast cancer and implementation of early diagnosis methods affect one's perception of successful health behaviors -that is, self-efficacy- which starts and continues positive health behaviors. Additionally, it is known that individuals who have family breast cancer history feel under risk for breast cancer and therefore are more susceptible towards and care about cancer more. ${ }^{13,15-17,22}$ According to HBMS, increase in susceptibility and seriousness augments health motivation and reduces barrier and encourages women to perform positive health behaviors like BSE and mammography and thus women have been persuaded in the benefits and efficacy of these methods. In the study of Powe et al., it was emphasized that women who had family breast cancer history believed the importance of early diagnosis methods more. ${ }^{22}$ The studies of Canbulat, Gerçek et al. and Kılıç et al. reported that women who had family breast cancer history were more susceptible towards breast cancer. ${ }^{13,15,17}$ Moreover; "susceptibility", "seriousness" and "self-efficacy" of the women who were aged 20-60 and who had family breast cancer history were higher in the study of Altunkan et al. ${ }^{16}$ In the study of Kiliç et al., girls with breast cancer knowledge were found to be more susceptible towards breast cancer, their "barriers to BSE" was lower and their "BSE self-efficacy" was higher. ${ }^{17}$ These findings were similar to our findings.

As a conclusion; it was detected that the participant female academicians were susceptible to breast cancer, cared about it, had higher health motivation. Also, our participants considered breast cancer screening methods useful and believed in BSE selfefficacy. However, participant women's barriers to BSE and their barriers to mammography were hig- her. Therefore; it was concluded that female academicians had negative health beliefs and attitudes towards BSE and mammography and therefore, avoided from these practices. However; it was established that female academicians who had family breast cancer history, had knowledge about breast cancer and whose specialty was on health were susceptible to breast cancer and cared about it more compared to other women and their barriers to BSE and barriers to mammography were lower. In light of the finding obtained from the research, it may be recommended that:

- Health care personnel who work at health service offices located at the universities should perform risk analyses of breast cancer for the female academician,

- Cancer risk groups should be detected,

- Planned health trainings to turn negative health beliefs of breast cancer and screenings into positive health beliefs and attitudes should be organized,

- Studies with bigger sample size and control groups should be planned so that prospective studies can provide more reliable results about this issue.

\section{REFERENCES}

1. Boyle P, Levin B. World Cancer Report 2008. Lyon France IARC Press, 2008.

2. The Ministry of Health of Turkey. Health Statics Yearbook 2010. Mollahaliloğlu S, Başara BB, Eryılmaz Z (eds). Ankara, Kalkan Publishing Company, 2011: 25.

3. Rosvold OE, Hjartaker A, Bjertness E, et al. Breast self-examination and cervical cancer testing among Norwegian female physicians A nation-wide comparative study. Social Sci \& Med 52: 259-258, 2001.

4. Petro-Nustus W, Mikhail BI. Factors associated with breast self examination among Jordanian women. Public Health Nurs 19: 263-271, 2002.

5. Jarvandi S, Montazeri A, Harirchi I, et al. Beliefs and behaviors of Iranian teachers toward early detection of breast cancer and breast self-examination. Public Health 116: 245-249, 2002.

6. Ko C M, Sadler GR, Ryujin L, et al. Filipina American women's breast cancer knowledge, attitudes, and screening behaviors. BMC Public Health 3, 2003.

7. Durvasula RS, Regan PC, Ureno O, et al. Frequency of cervical and breast cancer screening rates in a multiethnic female college sample. Psychol Rep 99: 418420, 2006. 
8. Oluwatosin OA, Oladepo O. Knowledge of breast cancer and its early detection measures among rural women in Akinyele Local Government Area, Ibadan, Nigeria. BMC Cancer 6: 271, 2006.

9. Merey S. Breast Cancer Screening Behaviors of Women. Istanbul University Institute of Health Sciences, Public Health Nursing, Master Thesis, Istanbul, 2002.

10. Karayurt O, Dramalı A. Adaptation of Champion's Health Belief Model Scale to Turkish Women and Examination of the Factors Influencing the Frequency of Breast Self Examination. In: The First Regional Meeting of the Asian Pacific Organization for Cancer Prevention Congress Book. (APOPCP), Izmir, 2003: 154-155.

11. Aygın D, Uludag C, Sahin S. Evaluation of young people's knowledge, attitudes and behaviors about Brest-Self Examination. Hemsirelik Forumu Dergisi 7:1-6, 2004.

12. Dundar EP, Ozmen D, Ozturk B, et al. The knowledge and attitudes of breast self-examination and mammography in a group of women in a rural area in western Turkey. BMC Cancer 6: 1471-1407, 2005.

13. Canbulat N. Evaluation of Health Beliefs about breast cancer, breast self examination and mammography of Health personnel. Atatürk University Institute of Health Sciences, Surgical Diseases Nursing, Master Thesis, Erzurum, 2006

14. Nahcivan ON, Secginli S. Factors associated with breast cancer screening behaviors in a sample of Turkish women: A questionnaire survey. Int J Nurs Stud 43: 161-171, 2006.

15. Gercek S, Duran O, Yildirim G, et al. Health Beliefs about Breast Cancer and Breast Self Examination of female university students who stayed at State Dormitories and Determination of the affecting factors of their health beliefs. J Breast Health 4: 157-161, 2008.

16. Altunkan $H$, Akin B, Ege E. Breast Self Examination Behaviors of women aged 20-60 and their awareness level. J Breast Health 4: 84-91, 2008.

17. Killic D, Saglam R, Kara O. Evaluation of the Affecting Factors of Breast Cancer Awareness among University Students J Breast Health 5: 195-199, 2009.

18. Champion VL. Instrument Development for Health Belief Model Constructs. Adv Nurs Sci 6: 73-85, 1984.
19. Gozum S, Aydin I. Validation Evidence for Turkish Adaptation of Champion's Health Belief Model Scales. Cancer Nurs 27: 491-498, 2004.

20. Lostao L, Joiner T, Pettit JW, et al. Health beliefs and illness attitudes as predictors of breast cancer screening attendance. Eur J Pub Health 11: 274-279, 2001.

21. Dewal L. Testicular and breast self-examination knowledge and practices of certified athletic trainers and the secondary prevention of such cancers in intercollegiate student-athletes. Am J Health Studies 21: 28-35, 2006.

22. Powe BD, Underwood S, Canales M, et al. Perceptions about breast cancer among college students: Implications for nursing education. J Nurs Educ 44: 257-265, 2005.

23. Ozmen V. Breast cancer in the world and Turkey. J Breast Health 4: 7-11, 2008.

\section{Correspondence}

Nuriye Büyükkayacı DUMAN

Hitit Üniversitesi Sağllk Yüksek Okulu

ÇORUM / TURKEY

Tel: (+90.364) $2230730 / 3530$

Fax: (+90.364) $2230730 / 3531$

e-mail:nurfatihh@hotmail.com 